\title{
ARTICLES \\ VARIATION WITHIN IDIOMATIC VARIATION: \\ EXPLORING THE DIFFERENCES BETWEEN SPEAKERS AND IDIOMS
}

\author{
Kristina Geeraert \\ https://orcid.org/0000-0003-2526-5374 \\ geeraert@ualberta.ca \\ University of Alberta, Canada
}

John Newman

Scopus Author ID: $\underline{8270138000}$

https://orcid.org/0000-0002-9978-0689

john.newman@ualberta.ca

University of Alberta, Canada

Monash University, Australia

R. Harald Baayen

https://orcid.org/0000-0003-3178-3944

harald.baayen@uni-tuebingen.de

University of Tübingen, Germany

Received September 14, 2020; Revised November 22, 2020; Accepted November 24, 2020

\begin{abstract}
Corpus-based research on idiomatic variation has shown that idioms can be utilized with an extensive range of variation, including the possibility of idioms occurring with adjectival modification (e.g. make rapid headway), lexical variation (e.g. the calm/lull before the storm), and partial forms (e.g. birds of a feather [flock together]). Previous experimental research eliciting variation within idioms has tended to focus on unintended 'slips of the tongue', or errors in production. To date, no experimental study has explored the creativity that speakers can employ when using idioms. This study, by contrast, aims to elicit conscious and spontaneous productions of idiomatic variation, exploring just how creative speakers can be when using idiomatic expressions. Participants were asked to create headlines for newspaper snippets using provided idioms. They were explicitly told that the expression did not have to be exact and that they could be as creative as they wanted. The headlines for each idiom and each speaker were then examined. Variational patterns are observed for both idioms and speakers. For instance, some idioms (e.g. jump on the bandwagon) typically occur with partial forms, lexical variation, and/or adjectival modification; whereas other idioms (e.g. call the shots) are predominantly used in their canonical form. Similarly, some speakers (e.g. Speaker 14037) demonstrated considerable flexibility and playfulness when using the expressions, while other speakers (e.g. Speaker 14020) preferred minimal, if any, modification to the idioms. These results not only converge with
\end{abstract}

(C) Geeraert, Kristina; Newman, John; Baayen, Harald R., 2020.

This is an Open Access article distributed under the terms and conditions of the Creative Commons Attribution 4.0 International Licence (https://creativecommons.org/licenses/by/4.0/). East European Journal of Psycholinguistics, 7(2), 9-27. https://doi.org/10.29038/eejpl.2020.7.2.gee 
previous corpus-based findings, but they also highlight the individual differences between speakers, as well as reveal how creative and innovative speakers can be when using idiomatic

Keywords: idioms, idiomatic variation, creativity, experimental, person-oriented, English.

Геерерт Крістіна, Ньюмен Джон, Бааєн Гаральд. Варіація в межах ідіоматичної варіації: дослідження відмінностей уживання ідіом різними мовцями.

Анотація. Дослідження, що базуються на основі щодо ідіоматичних змін, показали, що ідіоми можуть бути використані 3 широким діапазоном варіацій, включаючи можливість ідіом, що виникають із модифікацією прикметника (напр., make rapid headway), лексичними варіаціями (напр., the calm/lull before the storm), а також часткові форми (напр., birds of a feather [flock together]). Попередні експериментальні дослідження, що спричиняють варіації в ідіомах, як правило, зосереджувались на ненавмисних «обмовках» або помилках під час породження мовлення. Сьогодні немає експериментальних досліджень щодо творчих здібностей мовців під час послуговування ідіомами. Тому це дослідження має за мету викликати свідомі та спонтанні породження ідіоматичних варіацій, вивчаючи, наскільки творчими можуть бути мовці, використовуючи ідіоматичні вислови. Учасників попросили створити заголовки для газетних фрагментів, використовуючи надані ідіоми. Їм прямо сказали, що вираз не повинен бути точним і що вони можуть бути настільки творчими, наскільки захочуть. Потім було вивчено заголовки кожної ідіоми та кожного доповідача. Варіаційні закономірності спостерігаються і для ідіом, і для мовців. Наприклад, деякі фразеологізми (напр., jump on the bandwagon) зазвичай трапляються з частковими формами, лексичними варіаціями та / або модифікацією прикметника; тоді як інші ідіоми (напр., call the shots) переважно використовуються у їх канонічній формі. Подібним чином деякі мовці (напр., мовець 14037) демонстрували значну гнучкість та грайливість при використанні виразів, тоді як інші мовці (напр., мовець 14020) віддавали перевагу мінімальним, якщо такі $\epsilon$, модифікаціям ідіом. Ці результати не лише збігаються з попередніми висновками на основі корпусу, але вони також висвітлюють індивідуальні відмінності між мовцями, а також виявляють, наскільки креативними та інноваційними можуть бути мовці під час використання ідіоматичних виразів.

Ключові слова: ідіоми, ідіоматична варіація, креативність, експериментальний, особистісна орієнтація, англійська мова.

\section{Introduction}

Research on idioms has a long history of focusing on the canonical form, as it was assumed that the idiomatic meaning was only understood when the exact form of the idiom was used. Recent research however has begun to explore idiomatic variation within corpora (cf. Moon, 1998; Barlow, 2000; Langlotz, 2006; Wulff, 2008; Duffley, 2013; Schröder, 2013). Moon (1998) conducted an extensive investigation of idioms and fixed expressions and found that idioms can occur with a range of variation; for example, lexical variation (e.g. the calm/lull before the storm), truncations (e.g. birds of a feather [flock together]), register variation (e.g. knock someone dead vs. knock 'em dead), dialectal variation (e.g. wear the trousers [BrE] vs. wear the pants [AmE]), and even 'erroneous' forms (e.g. whet someone's appetite vs. wet someone's appetite). Schröder (2013) found that 'fixed idioms' (e.g. kick the bucket) and 'mobile idioms' (e.g. spill the beans) had significantly fewer tokens of syntactic variation, compared with 'metaphor idioms' (e.g. make 
headway), but that all three types can occur with adjectival and adverbial modification (e.g. make rapid headway).

Studies have also utilized the internet as a corpus to further explore idiomatic variation. Barlow (2000) observed several ways in which the current situation can be conceptually integrated into an idiom; for example, full noun phrases integrated into the subject position (e.g. No competition is over until the fat lady sings) or partial forms alluding to the whole idiom (e.g. The fat lady burst into song far too early last Sunday). Duffley (2013) showed that even nondecomposable idioms (e.g. kick the bucket and shoot the breeze) can undergo variation, such as adjectival modifiers (e.g. reluctant to kick his brimming bucket of life) and even passives (e.g. breeze is shot, piss is taken, and a bit of fun is had). These examples illustrate that idioms are not nearly as fixed or 'frozen' as previously assumed, but can actually occur with a remarkable amount of variation.

Few studies have explored the production of idiomatic variants. Cutting and Bock (1997) investigated the production of formal idiom blends. They presented two idioms to participants, and after a short delay, asked for one of the idioms. They were attempting to induce blends, which are often regarded as 'slips of the tongue' (Fay, 1982). They found that blends are more likely to be produced if the syntax and the semantics of the two idioms are similar. Recently, Konopka and Bock (2009) examined the production of phrasal verbs which could have an idiomatic interpretation (e.g. pull off a robbery) or a literal one (e.g. pull off $a$ sweater). Using a priming study, they attempted to induce production errors in the syntax of the phrasal verb (i.e. the particle occurring after the verb or after the object). They found that phrasal verbs were influenced by the prime and produced with a similar structure, concluding that idiomatic phrasal verbs can be altered as much as non-idiomatic phrasal verbs.

These production studies may be important for theories of speech production, but they do not account for deliberate, intentional variation, or the range of variation that can be naturally produced by speakers. This study therefore focuses on idiomatic variation that can be spontaneously and consciously produced by speakers of English. One way to elicit variation may be to ask participants to produce newspaper headlines. Glancing through any newspaper, one can immediately see that idioms are used in headlines to attract reader's attention (e.g. Legit massage therapists rubbed the wrong way). Providing participants with an opportunity to be as creative as they like should confirm already known uses of idioms, as well as reveal novel uses. The current study attempts, therefore, to explore how creative speakers can be with idioms when prompted.

\section{Methodology}

\subsection{Materials}

Sixty idioms and their definitions were selected from the Oxford Dictionary of English Idioms (Ayto, 2009) and the Collins COBUILD Idioms Dictionary (Sinclair, 2011). The idioms varied in length, from two to eight words, and syntax, including verb phrase idioms (e.g. call the shots), prepositional phrase idioms (e.g. down the drain), noun phrase idioms (e.g. a needle in a haystack), and sentential idioms (e.g. it's not over until the fat lady sings). Each idiom was paired with a 
newspaper snippet, ranging between three and six sentences in length. These snippets were extracted from the Strathy Corpus of Canadian English (Strathy Language Unit, 2013) and the Corpus of Contemporary American English (Davies, 2008), specifically from the newspaper genre.

\subsection{Procedure}

Participants were asked to create headlines for newspaper snippets. They were told to pretend they were the journalist who had just written the article and now must produce a headline. They were asked to include the provided idiom in their headline, but told that it did not have to be exact. They were also encouraged to be creative.

The experiment was created using E-prime 2.0 Professional. The text was presented in a bold, white, Courier New 24-point font on a black background. Before each newspaper snippet, participants were asked if they knew the idiom ('yes' or 'no'). If they did not know the idiom, a definition was provided. They then saw the newspaper snippet, along with the idiom, presented on the same screen. The snippet was positioned at the top of the screen, spanning $75 \%$ of the screen's width. The idiom appeared below the snippet, in the centre of the screen, identified by "Expression". A text box appeared below the idiom, in the bottom-half of the screen. Participants were required to write their headline in the text box, before continuing on to the next idiom-snippet pair. The experiment was self-paced. All participants had an opportunity to take a short break halfway through the experiment.

All participants saw the same 60 idiom-snippet pairs, presented in random order. They also saw the same example idiom and snippet, shown in (1). Three example headlines were created, shown in (2). Headline (A) utilizes a partial form of the idiom (mouthful of foot), Headline (B) blends two idioms: born with a silver spoon in one's mouth with put one's foot in one's mouth, while Headline (C) uses lexical variation (boot instead of foot). Participants saw only one example headline. After the example, they were given four practice headlines.

(1) Example Snippet:

U.S. Rep. Charles Rangel told the New York Times: "Mississippi gets more than their fair share back in federal money, but who the hell wants to live in Mississippi?" It led to a firestorm of newspaper attention. "I was trying to explain why the federal government gives more to a different state," Rangel says. "You have more poor folks in Mississippi than in New York."

Example Idiom:

put one's foot in one's mouth

(2) Example Headlines:

A. Mouthful of foot: Rangel comment causes uproar

B. Rangel, born with a silver foot in his mouth

C. Rangel's comment put the whole boot in his mouth 
After the experiment, participants were presented with a few additional questions. They were first asked three questions pertaining to their idiom usage: (1) How often do you use these expressions?; (2) How often do others around you use these expressions?; and (3) Do you like using these expressions? They responded to these questions using a 7-point Likert scale (i.e. $1=$ 'dislike' and 7 = 'like'). They were next asked to rate the acceptability of seven prescriptively 'incorrect' sentences, shown below, using the same 7-point scale.

Language Questions (LQ):

1. The only option the school board has is to lay off a large amount of people.

2. Slot machines are thought to be more addicting than table games.

3. The document had to be signed by both Susan and $\underline{I}$.

4. While cleaning the kitchen, Sally looked up and saw a spider on the roof.

5. I thought it could've went either way.

6. She could care less what he had to say about it.

7. You have to balance your life, irregardless of what anybody thinks.

\subsection{Participants}

Thirty undergraduate linguistics students from the University of Alberta participated in this experiment, ranging from 18 to 39 years of age. All participants considered themselves native speakers of English. Participants were compensated for their time with course credit.

\section{Results}

\subsection{Idioms}

We look specifically at five selected idioms (produced by the 30 participants) and discuss the variation and creativity used with these idioms in the elicited newspaper headlines. Each of the five idioms demonstrate a different usage pattern of variation, worthy of discussion.

\subsubsection{Call the Shots}

Some idioms, such as call the shots and pull the plug, show little variation in the headlines. The variation evident with call the shots is especially minimal - the verb occurs in either the progressive form calling, see (3), or in the present tense form call, see (4). All instances utilize the canonical structure, with no alternations besides altering the aspect of the verb.

(3) a. Who is Really Calling the Shots?

b. Are Billionaire Sponsors Really Calling the Shots in our elections?

c. Cut out the Middle Men: We Know it's the Billionaires Calling the $\underline{\text { Shots }}$

(4) a. Billionaires who call the shots should have to explain them

b. Billionaires Play Puppeteer and Call the Shots

c. Rich sponsors call the shots on presidential campaigns 


\subsubsection{Jump on the Bandwagon}

Idioms, such as jump on the bandwagon and hear something through the grapevine, occur with a wide range of variation, occurring predominantly with adjectival modification and a richness of creativity mostly due to the salience of bandwagon and grapevine. The majority of headlines utilize the full form of the idiom, shown in (5a), although some show minor modification (e.g. omission of the). Half of the headlines occur with adjectival modification, integrating an additional concept into the idiom. Example (5b) shows the incorporation of snazzy lookin', which may reflect the participant's attitude about school uniforms, while (5c) includes the use of uniform itself - the most-utilized modifier in the headlines. This example also illustrates lexical variation, one of two instances which alter the verb, and syntactic variation, particularly the use of the progressive aspect, which was the most frequent type of syntactic variation with this idiom.

(5) a. Beaconsfield High School refuses to jump on the bandwagon: students and parents voted No to introducing uniforms into the school

b. Beaconsfield High not to jump on this snazzy lookin' bandwagon

c. Beaconsfield won't be joining the uniform bandwagon

d. Beaconsfield sees bandwagon in uniform, refuses to jump on

e. Students and parents vote to stay off bandwagon

f. Uniformed wagons making way down Montreal

g. Uniforms as the new bandwagon?

The remaining examples show the considerable degree of creativity that speakers can utilize with idioms like jump on the bandwagon. The salient word bandwagon in (5d) has been separated from the rest of the idiom (i.e. jump on), but more importantly, blended into a rich imagery of the bandwagon dressed in uniform, playing on the notion that bands, who traditionally rode on these wagons, wore uniforms, meanwhile conveying that a particular school chose not to implement a dress code. Example (5e) utilizes a partial form of the idiom (i.e. bandwagon), but in a context that expresses the opposite notion of the idiom staying off as opposed to jumping on. Example (5f) has drastically truncated the idiom so that all that appears is a portion of the salient word (i.e. wagons). This usage not only conveys the idiom, specifically that support for school uniforms is spreading through the city of Montreal, but also that decorated physical wagons might be travelling alongside the hype. The last example, $(5 \mathrm{~g})$, shows an instance of a formal idiom blend, blending the expression $X$ is the new black with jump on the bandwagon. This example merges the popular, support-driven bandwagon with the latest fad, the new black. Creativity is also observed in how the participants describe the lack of jumping on by the particular school. This school refuses to jump on, stays off, and even misses the bandwagon. The school jumps on the bandwagon against uniforms, says no, and simply won't be joining. The range of variation in describing how this school declined jumping on the bandwagon is itself noteworthy. 


\subsubsection{It's Not Over Until the Fat Lady Sings}

Some idioms have more than one salient word, such as it's not over until the fat lady sings, where fat, lady, and sing are all salient. These idioms tend to have one or more elements in the idiom replaced, or are used with a greater array of partial forms. The full form appears in about half of the headlines, but most occur with slight modification to the form, such as it's not over becoming it isn't over, it ain't over, and even not over, as illustrated in (6a). A new noun phrase is often incorporated into the initial subject position (i.e. replacing $i t$ with a noun relevant to the current situation), as shown in (6b). Modification of a noun phrase is also observed with the fat lady, where this NP is replaced with one that is more relevant to the current situation, such as (6c).

(6) a. Christian Right lobbyists claim that it isn't over until the fat lady $\underline{\sin g s}$

b. The proposal is not over until the fat lady sings

c. Not over until lawmakers sing, lobbyists say

d. Statehouse Regulars are keeping pressure on lawmakers until the fat lady sings

e. The fat lady hasn't sung yet, she's simply heavily sedated

f. Opponents Refuse to Listen to the Fat Lady

g. No singing heard yet at the legislative session

Partial forms of the idiom are also commonly used, containing elements of varying lengths from the second half of the expression, such as until the fat lady sings, seen in (6d), or with the elements fat, lady, and sing, as in (6e). This latter use typically includes these three elements in a negative past-participial construction (i.e. the fat lady hasn't sung), although they can also occur in other constructions, such as the fat lady may still sing or when will the fat lady sing. Other partial forms can be utilized, such as those containing only the fat lady (see 6f) or only the verb sing (see $6 \mathrm{~g}$ ). In these instances, reference is made to the fact that she or the singing cannot be heard yet, or alternatively, that someone chooses not to listen. The majority of headlines convey the idea that the fat lady has not begun her singing, only one headline manipulates this idea to convey that she is being ignored (i.e. refuse to listen), while a different headline conveys that she has not quite finished (i.e. the fat lady is still singing). These results nicely overlap with Barlow's (2000) corpus-based findings.

\subsubsection{Down the Drain}

While prepositional phrase idioms, like down the drain and in the bag, are not manipulated to the same extent as idioms like jump on the bandwagon or it's not over until the fat lady sings, they still occur with variation and creativity. The majority of headlines show down the drain in its full canonical form; however, variation appears with whether a verb is utilized with the expression, and if so, the type of verb that occurs. In (7a), no verb appears; the expression is simply 
juxtaposed with another season to signal that the latest season is down the drain. This expression mostly occurs with generic verbs (e.g. be or go), indicating the season is simply lost or wasted, as shown in (7b).
a. Another Season Down the Drain? NHL Negotiations Continue
b. Bettman pulls the plug and a new collective bargaining agreement goes down the drain
c. NHL season - slipping down the drain
d. Is the NHL throwing the season down the drain?
e. Possibilities of NHL season slowly washed down the drain
f. Bettman flushes the season down the drain
g. Negotiations, and the season, sliding towards the drain
h. Is this years NHL season headed for the drain?
i. Hopes of lockout-free season swirling around the drain as sides unable to find common ground

Down the drain can also be utilized with very manner-rich verbs, seen in $(7 \mathrm{c}-$ 7i). These manner-rich verbs describe and elaborate on the way in which something abstract has become lost or wasted. This expression occurs with 10 different manner-rich verbs in the headlines, including two verbs which play on the literal meaning of the expression, washed and flushed, in (7e) and (7f). Other information within the headline can also allude to the literal meaning of the expression, such as incorporating another idiom, pull the plug, which is creatively employed to construe an intimately related literal and figurative reading of the headline, shown in (7b). Lexical variation is also observed, specifically altering the preposition, seen in $(7 \mathrm{~g}-7 \mathrm{i})$. Using different prepositions provides a resourceful way to convey the delayed, drawn-out process of the context (i.e. problematic negotiations resulting in a lost hockey season).

\subsubsection{Cost an Arm and a Leg}

Some idioms, like cost an arm and a leg and show one's true colours, show a surprising amount of creativity and allusion. About half the headlines utilized the idiom in its full form, demonstrated in (8a), although some instances included someone being referenced within the idiom, such as you, shown in (8b). Lexical variation is also observed with this idiom, usually with the verb, seen in (8c). The remaining examples illustrate just how creative speakers can be. A variety of partial forms were observed with this idiom, such as the variant an arm and a leg, see (8d), or its plural counterpart, in (8e). Participants also used the verb cost as a partial form, with some additional referent, such as limb in (8f), or two of each in $(8 \mathrm{~g})$. Finally, a few headlines do not contain any portion of the idiom, but simply allude to the idiomatic meaning using other words, typically limbs, as in (8h). These examples not only show exceptional creativity, but they also show extreme 
allusion - reference to the idiomatic meaning with a minimal form only or by using no actual words from the idiom whatsoever.

(8) a. Night on the town costs an arm and a leg

b. Dinner in San Francisco can cost you an arm and a leg

c. Date Nights Going for an Arm and a Leg in San Francisco's Civic Center

d. San Francisco date night receipt: An arm and a leg

e. Forget losing your heart-dating takes your arms and legs

f. Trip to Civic Center May Cost A Limb

g. Thankfully you have two of each: Civic Center's costly experience

h. Is a night out worth the loss of limbs?

This 'extreme allusion' (i.e. allusion to the idiom without using any formal portion of the idiom) is likely a task effect. Both the participants and the experimenter knew the idiom being referenced, as well as the context of the newspaper snippet. Therefore, accessing the idiom's meaning from the allusion is still possible despite no formal portion of the idiom. If, for example, $(8 \mathrm{~h})$ was a real headline in a newspaper, the idiomatic meaning would likely be lost on the audience. In fact, a quick search through 200 concordance lines for limb and limbs in the Strathy Corpus of Canadian English (Strathy Language Unit, 2013) and the Corpus of Contemporary American English (Davies, 2008) yielded zero instances where this word appears to be alluding to the idiom cost an arm and a leg. This suggests that extreme allusion is only possible when all parties involved have the same 'shared knowledge', making these allusions akin to inside jokes. This shared knowledge is what allows the idiomatic meaning to still be interpretable. Regardless of the limitations of this variant, it is impressive that speakers are able to be so exceptionally creative with idioms under the right conditions.

\subsection{Speakers}

We now turn our attention to speaker-specific headlines, exploring patterns observed in the headlines for certain participants, as well as discussing their responses to the additional questions included at the end of the experiment. For this section, we draw upon the "person-oriented approach" (Bergman and Lundh, 2015), which employs a methodology of focusing on the individual and studying patterns from an indivisible whole, rather than as part of an aggregate. This approach allows us to complement the idiom-specific discussion above and highlight patterns and strategies specific to certain individuals (i.e. to look at the individual differences of the participants; cf. Dąbrowska, 2012, 2015). Five speakers will be discussed in detail below. The results of the additional experimental questions (e.g. Do you use idioms often?) for all five speakers are illustrated in Figure 1 and shown in detail in the Appendix. 
Figure 1.

Speaker response profiles
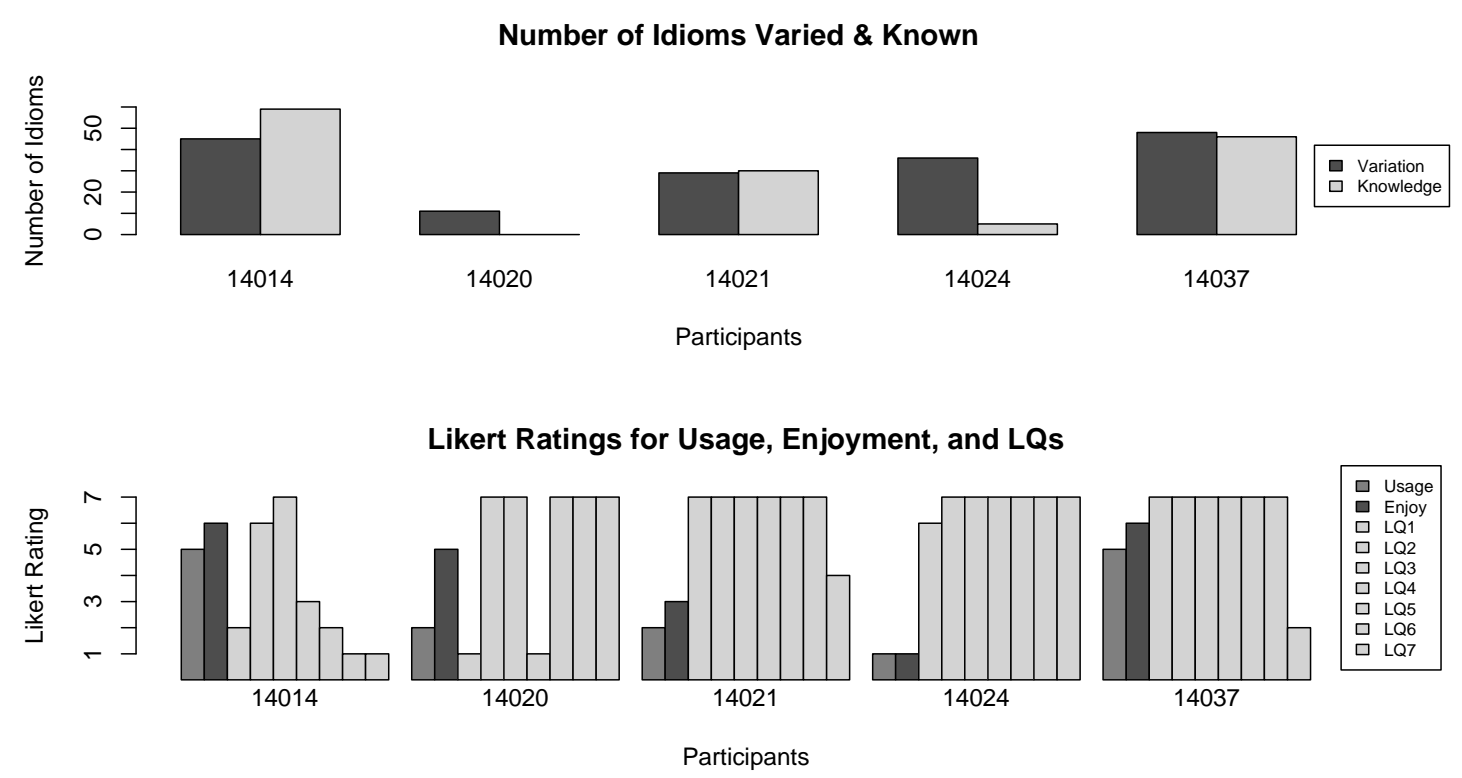

Note. The top panel illustrates the number of idioms (out of 60) which were varied by each speaker ('Variation') and that the speaker indicated knowing ('Knowledge'). The bottom panel illustrates the Likert ratings (1 'lowest' 7 'highest') for each speaker for how often they use idioms in general ('Usage'), if they enjoy using idioms ('Enjoy'), and their responses to each prescriptively incorrect sentence, or 'Language Question' ('LQ'), shown in consecutive order.

\subsubsection{Speaker 14020}

Some speakers employ very little variation, preferring to use the canonical form (i.e. the form of the idiom that was presented to the participants). Speaker 14020 produced just 11 headlines that contained a deviation from the canonical form. The majority of these employed syntactic variation, modifying the tense or aspect. Example (9a) shows the verb in the progressive, the most common type of modification for this speaker, while (9b) occurs in the passive.

\section{(9) a. Turning a blind eye on human rights issues}

b. Water Pipes being nipped in the bud for containing worse chemicals than cigarettes

This speaker used a few variation strategies, but minimally, only showing one instance each. In (10a), a full noun phrase is integrated into the subject position, replacing it. (10b) shows the integration of additional information: school and uniform, which are incorporated into the idiom to describe the type of bandwagon that is being boarded. (10c) shows a partial form of the idiom, containing only the body parts of the expression. While (10d) uses the idiom as an adjectival modifier to modify the head noun. These examples illustrate that this speaker occasionally utilizes variation, but mostly prefers the idioms in their canonical form. 
(10) a. The politics aren't over until the fat lady sings

b. Beaconsfield High School does not jump on school uniform Bandwagon

c. An Arm and A Leg for a Night at San Francisco's Civic Center

d. The San Francisco Fire Credit Union increases memberships through a no strings attached system

We will now address the additional questions (see Figure 1) that were asked to obtain a better understanding of why the participants might respond the way they do - in line with a person-oriented methodology. The most striking observation is the fact that this speaker indicated that she did not know any of the idioms used in this experiment - she knew the first idiom in the practice and then not a single idiom afterwards. She also indicated that she does not use idioms often. This suggests one of two possibilities: 1) either she truly does not know the vast majority of idioms used in this study despite acquiring English as a first language; or 2) she does not use idioms very often and therefore was not confident in knowing their meanings. Definitions were only provided if participants indicated that they did not know an idiom. This speaker likely indicated 'no' for all idioms to ensure that she was subsequently provided with the definition for all (unfamiliar and semi-familiar) idioms. Her unfamiliarity and limited usage with idioms likely affected her desire to modify these expressions, opting to use the expressions exactly as they were presented to her, thereby producing headlines containing few variants.

This speaker rated LQ1 and LQ4 as being completely unacceptable, both of which contained a similar word in place of the 'correct' word: amount for number (LQ1) and roof for ceiling (LQ4). Perhaps this speaker prefers clarity - using the 'correct' word to avoid confusion. This preference may also explain why she employed minimal variation, opting to clearly convey the idiomatic meaning with the canonical form.

\subsubsection{Speaker 14037}

Some speakers use a vast amount of variation with a wide range of variational strategies. Speaker 14037 enjoyed altering the idioms and demonstrated how flexible and creative some speakers can be when using these expressions. This speaker used the canonical form twelve times; all other headlines contained some kind of variation.

The examples in (11) show instances of lexical variation. (11a) shows the alternation of a word to another largely synonymous word, while (11b) and (11c) illustrate semantically productive lexical variation, where contextual information is integrated into the expression (cf. McGlone et al., 1994). In (11b), steam has been replaced by a festival organizer's name, Serge, suggesting that the festival is moving ahead with full force, but that it is largely due to the efforts of the organizer. In (11c) the verb cut has been replaced with fix, implying that shortcuts have already been made and repairs to those cuts are now underway. 


\section{(11) a. Cape Breton facing Brunt of storm [bear the brunt of something] \\ b. Full Serge Ahead [full steam ahead] \\ c. Fixing Corners postpones restaurant launch [cut corners]}

The examples in (12) blend elements from different expressions. Two idioms: come to grips with something and come apart at the seams are blended into the form gripping at the seams in (12a). This blend suggests that not only is the housing market having some difficulties, but that perhaps home sellers are not ready or able to accept it. Example (12b) blends two idioms (i.e. have one's fingers in every pie and have your cake and eat it too) while merging content from the newspaper snippet. Exchanging the verb of possession with a more contextually relevant verb, design, incorporates the business represented in the snippet (Designer's Guild), as well as the idea that one can be involved in everything, linking the meaning of the original provided idiom with the variant. The headline in (12c) semantically blends two expressions by juxtaposing them and referencing the provided idiom (i.e. worth your salt) within another similar idiom (i.e. worth your weight in gold).

\section{(12) a. Gripping at the seems, House market benefits buyers}

[come to grips with something] \& [come apart at the seams]

b. Design your pie and eat it too; Guild spills on doing it all

[have your fingers in every pie] \& [have your cake and eat it too]

c. No Salt needed at El Hihalguense, Their worth their weight in it

[worth your salt] \& [worth your weight in gold]

This speaker creatively plays on the literal meaning of an idiom. The literal meaning 'to allow water to flow down a drain' is referenced in (13a) by suggesting that Facebook drowns, or fails as a company, when staff are no longer allowed to check their accounts at work. (13b) juxtaposes the concepts of one playing with a water gun and the difficult topics discussed by the former president of the USA. These examples showcase the ability of some speakers to playfully manipulate semantic elements.

This speaker also utilizes allusion, often with a partial form of the idiom, though not necessarily a salient word. (13c) plays with the idea of crow as food while alluding to the idiomatic meaning of eat crow. In (13d), the word mountain is used to allude to the idiom make a mountain out of a molehill. This headline references the resultative state of the expression by indicating that the media has found itself in a 'mountainous' situation and now must dig its way out. In (13e), no formal words of the idiom are included in the allusion; instead, the words clawing out allude to a cat freeing itself, and a secret being revealed.

(13) a. Facebook drowns as company pulls plug on staff FB use

b. Shooting the Breeze with a Water Gun; Obama talks hard issues

c. Crows on the Menu for Rangel [eat crow] 
d. Digging its way out of a mountain, how the media is trying to reclaim respect [make a mountain out of a molehill] e. Advisors Clawing Out [let the cat out of the bag]

As demonstrated by these examples, this speaker is quite playful with idioms and is willing to manipulate them in a variety of ways for various effects. She rated her enjoyment of using idioms quite high and indicated that she uses them fairly often. This greater enjoyment and increased usage may influence this speaker's desire to play with idioms more. Moreover, this speaker indicated that she knew the majority of idioms, potentially providing her with greater familiarity of idioms in general, and with each idiom in particular. Yet this speaker was still willing and able to creatively alter unfamiliar expressions, like eat crow (see 13c). Altering the majority of idioms to some degree, including novel expressions, further demonstrates the playful character of this speaker and shows this speaker's flexibility with idiomatic language.

This speaker's flexibility with language is also observed in her responses to the LQs. She rated almost all of them as being perfectly acceptable; only LQ7 received a rating of not acceptable. This sentence contains the word blend irregardless, combining regardless and irrespective - a form which sometimes elicits a strong reaction to its "non-word status". This sentence is the only one that contains a non-word, suggesting that this speaker is accepting of manipulating and playing with language in novel and innovative ways, but only with 'conventionalized' words, or words already accepted in language. Thus, the playful quality of this speaker is guided by grammatical 'rules' of the language and the conventions of others.

\subsubsection{Speaker 14024}

The next three speakers have been chosen to illustrate that some speakers tend to rely on specific variational strategies in their headlines. These speakers all show moderate amounts of variation, with the majority of variants demonstrating a consistent type. Speaker 14024 modified approximately half of the idioms (i.e. 36 headlines contained variation), but the majority of these ( 29 headlines) contained syntactic variation, primarily inflecting the verb for progressive aspect, although occasionally other syntactic alternations were used, see (14).

(14) a. Kerr not cutting corners for the launch of his new restaurant!

b. P.E.I. gaining ground in the medical field

c. Ontario nurses chomping at the bit

d. Cape Breton bearing the brunt of the winter storm

e. Shouldn't have bit off more than one can chew

Using syntactic variation with idioms does not seem very innovative. In fact, idioms altered for the progressive were rated as the most accepted syntactic variant (Gibbs and Nayak, 1989), while verb morphology (e.g. tense, aspect, mood) is the 
most flexible element in an idiom (Wulff, 2008). This strategy may therefore seem like a safe way to use idioms.

This speaker indicated that she does not like using idioms nor does she use them very often. She also indicated that she did not know most of the idioms included in this study. Unfamiliarity with the expressions and a preference to not use them may have lead this speaker to minimally vary the idioms. Interestingly, this speaker finds all LQs acceptable. This finding may suggest that she is accepting and flexible with language in general, and does not necessarily mind grammatically 'incorrect' usage, but tends not to be too daring in her own usage, at least not with expressions that she does not enjoy using.

\subsubsection{Speaker 14021}

Speaker 14021 also primarily utilizes one variational strategy - the integration of additional information into the idiom. Approximately half of the headlines contained variation, and of these, 16 included modifiers inserted into the idiom. The examples in (15) illustrate the range of modifying information, from adjectives like tough (15a), passionate (15b), and symphonic (15c), to nouns like meteorite and countryside (15d), and result (15e), as well as one instance of an inserted phrase (15f).

a. Habitat back to the tough drawing board

[back to the drawing board]

b. Dad tells son to keep his passionate nose to the grindstone

[keep your nose to the grindstone]

c. Zinman ain't beatin around no symphonic bush

[beat around the bush]

d. Beech set on finding meteorite needle in the countryside haystack

[a needle in a haystack]

e. The Chinese let the result cat out of the bag

[let the cat out of the bag]

f. Guild has her fingers in every sort of project pie there is

[have your fingers in every pie]

This speaker indicated that he knew half of the expressions, but generally does not use idioms very often in his own speech, nor does he really like using idioms. This lower usage, but general familiarity, may make him more comfortable modifying the idioms with additional information, as opposed to altering the verb like the previous speaker. This strategy is quite common (cf. Gibbs and Nayak, 1989; Schröder, 2013), nevertheless the ability to integrate contextually descriptive elements, like symphonic or meteorite, is still creative.

This speaker's responses to the LQs are comparable to Speaker 14037 - all sentences are rated as perfectly acceptable, except for LQ7, which received midrange acceptability. This suggests a similar interpretation - this speaker is generally accepting or 'flexible' with language usage, as long as the words are already conventionalized or accepted within society. 


\subsubsection{Speaker 14014}

The final speaker uses variation in the majority of headlines (45 headlines contain variation), with the bulk of these containing some degree of allusion (28 instances). He tends to utilize a partial form of the expression to allude to the idiomatic meaning, shown in (16a-16e), but in some cases, alludes to the idiomatic meaning with no words from the idiom itself, see (16f).

\section{(16) a. Rotten Grapevine Fingered as Source of Riot}

[hear something through the grapevine]

b. No Bushes Stand in Zinman's Way [beat around the bush]

c. Coward Proves to be Anything But as he Bites Hands [bite the hand that feeds]

\section{d. Chinese Officials Leave Ballots after Releasing $\underline{\mathrm{Cat}}$}

[let the cat out of the bag]

\section{e. Recent Resident Counts Himself Lucky to Still Have Nose \\ [keep your nose to the grindstone] \\ f. Kerr's Restaurant Definitely Not Rounded [cut corners]}

These examples show exceptional creativity, especially (16f), where the idiomatic meaning is alluded to through the use of a truncated form, single word, or no formal words of the idiom. Remarkably, the words included in the allusion do not have to be salient words, like grapevine, but can also be non-salient words like nose. Some cases likely require further clarification to understand the connection between the headline and the idiom (i.e. knowledge of the newspaper snippet); however, these examples still show how extremely clever some speakers are when using idioms. The rampant creativity and playful behaviour demonstrated by this speaker may be explained by the fact that he indicated knowing all idioms except one, and had high ratings of idiom usage and enjoyment. The fact that he enjoys using idioms, uses them often, and is familiar with almost all of the expressions, likely contributed to his increased use of variation and his increased use of allusion.

Interestingly, this speaker only rated two sentences as being acceptable: LQ2 and LQ3. This suggests that he has a more formal understanding of what is considered 'acceptable grammar'. Yet he appears very willing to alter idioms to the point of unrecognizability. Perhaps these are not mutually exclusive - one can be innovative and imaginative with language, as long as 'proper' grammar is used.

\section{Discussion}

This study explored how creative speakers can be with idioms when prompted. The results of this study are in line with previous corpus-based research and reveal that the range of idiomatic variation is quite extensive; for example, participants frequently produced syntactic variation (e.g. the law is taken out of Harding's hands), adjectival modification (e.g. gains medical ground), and partial forms (e.g. media mountain more of a molehill). It is worth noting, too, that our procedure for eliciting idiom variants has led to the discovery of variants that would be quite difficult to locate and retrieve through corpus searches, such as 
partial forms or lexical variants containing non-salient words (e.g. cost a limb or around the drain). One would have to know which lexical items can reference an idiom (i.e. limbs for an arm and a leg), or search for common words in a context window (i.e. any preposition with drain), with no guarantee that an idiom variant will be found.

Extremely creative and novel uses were also observed, such as blending two distinct expressions (e.g. crossing one bridge at a time [cross that bridge when you come to it \& one $\mathrm{X}$ at a time]). The existence of formal idiom blends among the results is an exciting discovery. These variants have traditionally been regarded as errors or 'slips of the tongue' (Fay, 1982; Cutting and Bock, 1997). Even Langlotz (2006, p. 204), who specifically researched idiomatic creativity, classified formal idiom blends as "non-intentional erroneous variants". However, the results from this study suggest that while idiom blends are not very frequent, they are not simply errors, but can be one of the most imaginative variants. Idiom blends usually merge two idioms, like spills of the bag (spill the beans and let the cat out of the bag), similar to word blends. But they can also integrate contextual information into the blend, like uniforms as the new bandwagon (blending jump on the bandwagon and $X$ is the new black, while integrating uniforms, the topic of the newspaper snippet, into the blend). According to Kemmer (2003), word blends merge both formal properties and concepts, and as evident in this study, the same can be said about idiom blends.

Allusions are another example of speakers' originality and imagination. Some idioms, like cost an arm and a leg, were utilized extensively with allusion, sometimes exceptionally so, where no formal element of the idiom was used. This extreme use of allusion was likely a task effect - in other contexts and situations, alluding to an idiom through other words and no formal element of the idiom, the idiomatic meaning would likely be missed. Nonetheless, extreme allusion beautifully captures how flexible and innovative speakers can be with idioms under the right circumstances.

Subtle forms of creativity are also observed in the headlines. For example, playing on the literal meaning of a word from an idiom (e.g. Dermatology student risks skin by keeping his nose to the grindstone), playing on contextual elements from the newspaper snippet (e.g. Klutts Promises Not to Live up to His Name Given How Full his Plate is), and even the integration of additional concepts (e.g. Full Serge Ahead).

Looking specifically at individual idioms, we observed that idioms are utilized with different patterns of variation. Some idioms are utilized with few variants (e.g. call the shots), whereas others show a range of possible variants (e.g. jump on the bandwagon). More importantly, idioms show patterns as to how they are varied. Speakers prefer to preserve the salient word bandwagon if they truncate the expression jump on the bandwagon or alter it with adjectival modification. Compare this to it's not over until the fat lady sings, which has multiple salient words: fat, lady, and sing. This idiom is either modified using a variety of partial forms, utilizing one or more of the salient words, or alters an element within the 
idiom to a new concept. Finally, some idioms like down the drain predominantly occur in their canonical form with manner-rich verbs, but occasionally the preposition is altered for further elaboration. These observations illustrate that idioms are utilized and modified differently, likely influenced by their different syntactic structures.

We also looked specifically at individual speakers, who vary as to how creative they are willing to be with idioms. Some speakers alter idioms in various ways showing a playful quality and innovative flexibility with the language (Speaker 14037), while others seldom use variation and prefer to use expressions in their accepted and recognizable forms (Speaker 14020). Most participants, when they did vary the expressions, seemed to show a preference for one or a few types of variation. Speaker 14024 preferred syntactic variation, Speaker 14021 often utilized adjectival modification, while Speaker 14014 used partial forms to allude to the idiom. These results illustrate the individuality with which participants use idioms.

We asked participants about their knowledge and usage of idioms, as well as their acceptability of prescriptively 'incorrect' sentences (LQs), to explore whether these influenced how they altered idioms. Some generalizations can be made. For example, the more familiar the idiom (i.e. the more participants indicated that they knew the expression), the more they varied the expression in the headlines. The effects of idiom familiarity have been observed elsewhere (cf. McGlone et al., 1994; Titone and Connine, 1994), suggesting that knowledge of an idiom plays a fundamental role in idiom usage. In addition, the more the participants used idioms, and enjoyed using idioms, the more they varied the expressions in their headlines. This makes sense from a usage-based perspective - the more one enjoys using idioms, the more they will use them. And the more they use them, the more experience they have with them. The more experience they have, the more flexible they may become.

Looking at the headlines produced by individual speakers and for specific idioms nicely demonstrates that while speakers certainly differ in how and to what degree they prefer to alter idioms, they still show consistency in the way they vary certain idioms. Thus, the way individual speakers approached this task, shows their individual differences (cf. Dąbrowska, 2012, 2015), but their shared experiences with idioms led to similarities in how they modified them and resulted in a uniformity across speakers with specific idioms (cf. Divjak et al., 2016). It is important to include instances of individual differences in the discussion of language and not only focus on findings from aggregated data (Dąbrowska, 2016). We recognize that the latter is important for understanding generalizations about language, but we need to complement aggregated data by exploring individual usage to understand how one's experience with language and even one's attitudes towards language might influence their usage of language. 


\section{References}

Ayto, J. (Ed.). (2009). From the horse's mouth: Oxford dictionary of English idioms. Oxford: Oxford University Press.

Barlow, M. (2000). Usage, blends and grammar. In M. Barlow \& S. Kemmer (Eds.), Usagebased models of language (pp. 315-345). Stanford: CSLI Publications.

Bergman, L. R., \& Lundh, L.-G. (2015). Introduction: The person-oriented approach: Roots and roads to the future. Journal for Person-Oriented Research, 1(1-2), 1-6. https://doi.org/10.17505/jpor.2015.01

Cutting, J. C., \& Bock, K. (1997). That's the way the cookie bounces: Syntactic and semantic components of experimentally elicited idiom blends. Memory \& Cognition, 25(1), 57-71. https://doi.org/10.3758/BF03197285

Dąbrowska, E. (2012). Different speakers, different grammars. Individual differences in native language attainment. Linguistics Approaches to Bilingualism, 2(3), 219-253. https://doi.org/10.1075/lab.2.3.01dab

Dąbrowska, E. (2015). Individual differences in grammatical knowledge. In E. Dąbrowska \& D. Divjak (Eds.), Handbook of Cognitive Linguistics (pp. 650-668). Berlin/Boston: Walter de Gruyter. https://doi.org/10.1515/9783110292022-033

Dąbrowska, E. (2016). Cognitive linguistics' seven deadly sins. Cognitive Linguistics, 27(4), 479-491. https://doi.org/10.1515/cog-2016-0059

Davies, M. (2008). The corpus of contemporary American English: 450 million words, 1990present. Retrieved from: https://www.english-corpora.org/coca

Divjak, D., Dąbrowska, E., \& Arppe, A. (2016). Machine meets man: Evaluating the psychological reality of corpus-based probabilistic models. Cognitive Linguistics 27(1), 133. https://doi.org/10.1515/cog-2015-0101

Duffley, P. J. (2013). How creativity strains conventionality in the use of idiomatic expressions. In M. Borkent, B. Dancygier, \& J. Hinnell (Eds.), Language and the creative mind (pp. 4961). Stanford: CSLI Publications.

Fay, D. (1982). Substitutions and splices: A study of sentence blends. In A. Cutler (Ed.), Slips of the tongue and language production (pp. 163-195). Amsterdam: Mouton de Gruyter.

Gibbs, R. W., \& Nayak, N. P. (1989). Psycholinguistic studies on the syntactic behavior of idioms. Cognitive Psychology, 21, 100-138. https://doi.org/10.1016/0010-0285(89)90004-2

Kemmer, S. (2003). Schemas and lexical blends. In H. Cuyckens, T. Berg, R. Dirven, \& K.-U. Panther (Eds.), Motivation in language: Studies in honor of Günter Radden (pp. 69-97). Amsterdam/Philadelphia: John Benjamins.

Konopka, A. E., \& Bock, K. (2009). Lexical or syntactic control of sentence formulation? Structural generalizations from idiom production. Cognitive Psychology, 58(1), 68-101. https://doi.org/10.1016/j.cogpsych.2008.05.002

Langlotz, A. (2006). Idiomatic creativity: A cognitive-linguistic model of idiom-representation and idiom-variation in English. Amsterdam/Philadelphia: John Benjamins. https://doi.org/10.1075/hcp.17

McGlone, M. S., Glucksberg, S., \& Cacciari, C. (1994). Semantic productivity and idiom comprehension. Discourse Processes, 17, 167-190. https://doi.org/10.1080/01638539409544865

Moon, R. (1998). Fixed expressions and idioms in English. Oxford: Oxford University Press.

Schröder, D. (2013). The syntactic flexibility of idioms: A corpus-based approach. Munich: AVM.

Sinclair, J. (Ed.). (2011). Collins COBUILD idioms dictionary. Harper Collins.

Strathy Language Unit. (2013). Strathy corpus of Canadian English: 50 million words, 1970 2010. Retrieved from: https://www.english-corpora.org/can/

Titone, D. A., \& Connine, C. M. (1994). Descriptive norms for 171 idiomatic expressions: Familiarity, compositionality, predictability, and literality. Metaphor and Symbolic Activity, 9(4), 247-270. https://doi.org/10.1207/s15327868ms0904_1

Wulff, S. (2008). Rethinking idiomaticity: A usage-based approach. London/New York: Continuum. 


\section{Appendix}

Table 1.

Speaker responses to additional experiment questions.

\begin{tabular}{rccccccccccc}
\hline ID & Gender & Knowledge & Usage & Enjoy & LQ1 & LQ2 & LQ3 & LQ4 & LQ5 & LQ6 & LQ7 \\
\hline 14014 & $\mathrm{~m}$ & 59 & 5 & 6 & 2 & 6 & 7 & 3 & 2 & 1 & 1 \\
14020 & $\mathrm{f}$ & 0 & 2 & 5 & 1 & 7 & 7 & 1 & 7 & 7 & 7 \\
14021 & $\mathrm{~m}$ & 30 & 2 & 3 & 7 & 7 & 7 & 7 & 7 & 7 & 4 \\
14024 & $\mathrm{f}$ & 5 & 1 & 1 & 6 & 7 & 7 & 7 & 7 & 7 & 7 \\
14037 & $\mathrm{f}$ & 46 & 5 & 6 & 7 & 7 & 7 & 7 & 7 & 7 & 2 \\
\hline
\end{tabular}

Note. 'Knowledge' refers to how many idioms the speaker indicated they knew (out of 60). 'Usage' refers to how often the speaker uses idioms; 'Enjoy' refers to whether or not they enjoy using idioms in general; and each LQ (Language Question) is their response to each prescriptively incorrect sentence. These questions were rated using a Likert scale: 1 'lowest' to 7 'highest'.

LQ1: The only option the school board has is to lay off a large amount of people; LQ2: Slot machines are thought to be more addicting than table games; LQ3: The document had to be signed by both Susan and I; LQ4: While cleaning the kitchen, Sally looked up and saw a spider on the roof; LQ5: I thought it could've went either way; LQ6: She could care less what he had to say about it; LQ7: You have to balance your life, irregardless of what anybody thinks. 